\title{
MENGKONSTRUKSI NINE POINT CIRCLE DAN \\ HUBUNGAN NINE POINT CIRCLE DENGAN CIRCUM CIRCLE SEGITIGA
}

\author{
Oleh \\ I. P. Hendra Wijaya ${ }^{1}$, I. P. Pasek Suryawan ${ }^{2}$ \\ 1,2 Jurusan Matematika \\ Universitas Pendidikan Ganesha \\ Singaraja \\ e-mail: ${ }^{1}$ hendrawijayabalank@gmail.com, \\ 2putu.pasek@undiksha.ac.id
}

\begin{abstract}
ABSTRAK
Pada makalah ini dibahas mengenai cara dalam mengkonstruksi nine point circle dan hubungan antara nine point circle dengan circumcircle segitiga yang ditinjau dari jari-jari dan jarak titik pusatnya ke orthocentre. Diketahui bahwa melalui tiga buah titik yang tidak segaris selalu dapat dikonstruksi sebuah lingkaran, yang dapat juga disebut sebagai circumcircle dari segitiga yang titik-titik sudutnya merupakan tiga buah titik yang tidak segaris tersebut. Namun melalui empat buah titik yang tidak segaris sangatlah jarang dapat dikonstruksi lingkaran, kecuali keempat titik tersebut dapat membentuk segiempat tali busur. Mengingat untuk mengkonstruksi lingkaran yang melalui empat titik yang tidak segaris sangatlah susah, tidak terbayang bagaimana sulitnya untuk mengkonstruksi lingkaran yang melalui sembilan titik yang tidak segaris. Walaupun sangat sulit untuk menemukannya, tetapi ada kondisi khusus dari titik-titik tersebut sehingga kesembilan titik tersebut dapat dilalui oleh sebuah lingkaran, dan lingkaran yang terbentuk disebut dengan "nine point circle". Untuk dapat mengkonstruksi nine point circle dengan baik dan cepat, diperlukan tahapan-tahapan khusus yang nantinya menjadi panduan dalam mengkonstruksi lingkaran dari sembilan titik yang tidak segaris. Selain itu, jika nine point circle dibandingkan dengan circumcircle segitiga, maka didapatkan hubungan: (1) jari-jari nine point circlesama dengan setengah jari-jari circumcircle segitiga tersebut; (2) jarak titik pusat nine point circle ke orthocentre sama dengan setengah jarak titik pusat circumcircle ke orthocentre. Untuk kajian lebih lanjut terkait hubungan antara nine point circle dengan circumcircle dari segitiga dapat dilanjutkan oleh pembaca.
\end{abstract}

Kata kunci : nine point circle, circumcircle 


\begin{abstract}
In this paper we discuss how to construct the nine point circles and the relationship between nine point circles and the circumcircle triangle which is viewed from the radius and the distance of the center point to the orthocentre. It is known that through three points that are not in line, a circle can always be constructed, which can also be called the circumcircle of a triangle whose vertices are three points that are not in line. However, through four points that are not in line, it is very rare to construct a circle, unless the four points can form a rectangular string. Given to construct a circle through four points that are not in line is very difficult, it is not imagined how difficult it is to construct a circle through nine points that are not in line. Although it is very difficult to find it, but there are special conditions of these points so that the nine points can be passed by a circle, and the circle formed is called the "nine point circle". To be able to construct nine points circle well and quickly, special steps are needed which will later become a guide in constructing a circle of nine points that are not in line. In addition, if there are nine point circles compared to the circumcircle triangle, there is a relationship: (1) radius nine point circle is equal to half the radius of the circumcircle of the triangle; (2) the distance of the center point nine point circle to orthocentre is equal to half the distance of the circumcircle center point to the orthocentre. For further studies related to the relationship between nine point circles with the circumcircle of the triangle can be continued by the reader.
\end{abstract}

Keywords: nine point circle, circumcircle

\title{
PENDAHULUAN
}

Melalui tiga buah titik yang tidak segaris, selalu dapat dikonstruksi sebuah lingkaran, yang dapat juga disebut sebagai circumcircle dari segitiga yang titik-titik sudutnya merupakan tiga buah titik yang tidak segaris tersebut. Namun melalui empat buah titik yang tidak segaris sangatlah jarang dapat dikonstruksi lingkaran, kecuali keempat titik tersebut dapat membentuk segiempat tali busur. Mengingat untuk mengkonstruksi lingkaran yang melalui empat titik yang tidak segaris sangatlah susah, tidak terbayang bagaimana sulitnya untuk mengkonstruksi lingkaran yang melalui sembilan titik yang tidak segaris. Walaupun sangat sulit untuk menemukannya, tetapi ada kondisi khusus dari titiktitik tersebut sehingga kesembilan titik tersebut dapat dilalui oleh sebuah lingkaran, dan lingkaran yang terbentuk disebut dengan "nine point circle". 
Sebelumnya sudah dibahas dalam seminar matematika oleh Oka Dharmawan (2011) mengenai konsep- konsep dasar nine point circle. Dari pembahasan dalam makalah tersebut penulis dapat menyimpulkan bahwa nine point circle merupakan lingkaran yang melalui sembilan titik dimana titik- titik tersebut diperoleh dari sembarang segitiga.Tiga titik pertama merupakan titik tengah dari masing- masing sisi segitiga.Tiga titik berikutnya yaitu perpotongan garis tinggi dengan sisi segitiga dan tiga titik lainnya yaitu titik tengah dari segmen garis yang menghubungkan perpotongan garis tinggi dengan titik sudut dari segitiga tersebut.Untuk mengkonstruksi lingkaran yang melalui sembilan titik tak segaris ini dengan baik, diperlukan tahapan-tahapan tertentu. Jika melalui titik- titik sudut segitiga yang memuat nine point circle ini dibuat lingkaran, maka terbentuk circumcircle, sehingga akan menjadi hal menarik ketika dikaji mengenai hubungan antara nine point circle dan circumcircle dari segitiga yang memuat nine point circle tersebut.

Berdasarkan paparan di atas, penulis merasa tertantang untuk membahas materi terkait mengkonstruksi nine point circle dan hubungan antara nine point circle dengan circumcircle dari sembarang segitiga. Dalam makalah ini penulis mengangkat judul "Mengkonstruksi Nine Point Circle dan Hubungan Nine point circle dengan Circumcircle Segitiga ". karya tulis ini disusun untuk mengetahui cara mengkonstruksi nine point circle dan untuk mengetahui bagaimana hubungan antara nine point circle dengan circumcircle suatu segitiga.

\section{KAJIAN PUSTAKA}

Berikut ini akan dipaparkan beberapa teorema dasar dalam Geometri Euclids yang penulis kutip dari Wisna Ariawan (2008), yang digunakan dalam pengkajian ataupun pembuktian pada makalah seminar ini. Adapun teorema tersebut adalah sebagai berikut: (a)sudut-sudut yang bertolak belakang sama besar; (b) jika dua garis dipotong oleh garis lain sedemikian sehingga sudut sehadapnya sama besar, maka kedua garis itu sejajar; (c) jika dua garis sejajar dipotong oleh suatu garis, dua sudut sehadapnya sama besar.

Selain teorema dasar tersebut terdapat juga postulat tentang kekongruenan segitiga yaitu sebagai berikut: (a) Jika pada dua segitiga berlaku dua buah sisinya 
sama panjang dan sudut yang dibentuk kedua sisi tersebut sama besar, kedua segitiga tersebut kongruen; (b) Jika pada dua segitiga berlaku salah satu panjang sisinya sama dan dua sudut yang terletak pada sisi tersebut masing-masing sama besar, maka kedua segitiga itu kongruen.

Berikut ini adalah definisi dari rasio dan proporsi. Rasio adalah hasil bagi dari dua ukuran kuantitas yang satuan ukurannya sama dan proporsi adalah suatu persamaan yang melibatkan rasio pada kedua ruasnya.

Poligon $P_{1} P_{2} P_{3 \ldots} P_{n}$ dikatakan sebangun dengan poligon $Q_{1} Q_{2} Q_{3} \ldots Q_{n}$ jika dan hanya jika:

1. $m \angle P_{i}=m \angle Q_{i}$ untuk setiap $\mathrm{i}=1,2,3, \ldots, \mathrm{n}$ dan

2. $\frac{P_{1} P_{2}}{Q_{1} Q_{2}}=\frac{P_{2} P_{3}}{Q_{2} Q_{3}}=\ldots=\frac{P_{n} P_{1}}{Q_{n} Q_{1}}$

Jika suatu garis memotong dua sisi segitiga masing-masing atas bagian yang sama panjang, garis tersebut sejajar dengan sisi segitiga yang tidak terpotong.

Sebagai bangun datar, segitiga memiliki luas daerah. Luas daerah segitiga dapat ditentukan dengan rumus:

$$
L \Delta=\frac{1}{2} \times \text { alas } \times \text { ting gi }
$$

Luas daerah segitiga ini didapat dari penurunan luas daerah jajargenjang. Selain rumus tersebut, untuk menentukan luas daerah segitiga dapat menggunakan rumus:

$$
L \Delta=\sqrt{s(s-a)(s-b)(s-c)} \text {, dimana } s=\frac{1}{2}(a+b+c)
$$

Pada rumus tersebut, $a, b$, dan $c$ menyatakan panjang sisi-sisi segitiga.Rumus tersebut dikenal dengan Rumus Heron.

Berikut ini akan dipaparkan definisi dan teorema tentang lingkaran yang kutip dari Wisna Ariawan (2008) yang digunakan dalam pengkajian ataupun pembuktian pada makalah seminar ini. Definisi dan teorema tersebut antara lain: (a) Lingkaran adalah himpunan titik-titik yang berjarak sama terhadap suatu titik tertentu. Titik tertentu tersebut dinamakan pusat; (b) Jari-jari lingkaran adalah ruas garis yang menghubungkan titik pusat lingkaran dengan sebarang titik pada 
lingkaran; (c) Ukuran sudut keliling pada suatu busur lingkaran adalah setengah dari ukuran busur dihadapannya.

Berikut ini akan dipaparkan definisi dan teorema yang berkaitan dengan segiempat yang penulis kutip dari Wisna Ariawan (2008) yang digunakan dalam pengkajian ataupun pembuktian pada makalah ini. Definisi dan teorema tersebut antara lain: (a) Segiempat adalah poligon yang hanya memiliki empat buah sisi; (b) Jajar genjang atau disebut juga parallelogram adalah suatu segiempat yang pasangan sisi-sisi berhadapannya sejajar; (c) Pada suatu jajar genjang, sisi-sisi yang berhadapan sama panjang.

Segitiga tali busur pada suatu lingkaran adalah segitiga yang titik-titik sudutnya berada pada lingkaran.Lingkarannya selanjutnya disebut lingkaran luar dari segitiga (circumcircle).Pada sembarang segitiga dapat dibuat lingkaran luar yang titik pusatnya berada pada perpotongan garis-garis sumbu sisi segitiga tersebut. Jari-jari lingkaran luar (circumcircle) suatu segitiga sama dengan hasil kali ketiga panjang sisinya dibagi empat kali luas daerah segitiga tersebut.

Jika $\triangle A B C$ adalah segitiga dengan garis tinggi $\overline{A D}, \overline{B E}, \overline{C F}$, median $\overline{A U}, \overline{B V}, \overline{C W}$ dan Orthocentre H.Orthocentre adalah perpotongan dari ketiga garis tinggi dari suatu segitiga. Jika $A^{\prime}, B^{\prime}, C^{\prime}$ masing-masing merupakan titik tengah dari $\overline{A H}, \overline{B H}$, dan $\overline{C H}$, maka sembilan buah titik yaitu $A^{\prime}, B^{\prime}, C^{\prime}, D, E$, $F, U, V$, dan $W$ terletak pada sebuah lingkaran yang disebut nine point circle dari $\triangle A B C$. Perhatikan Gambar 15 berikut!

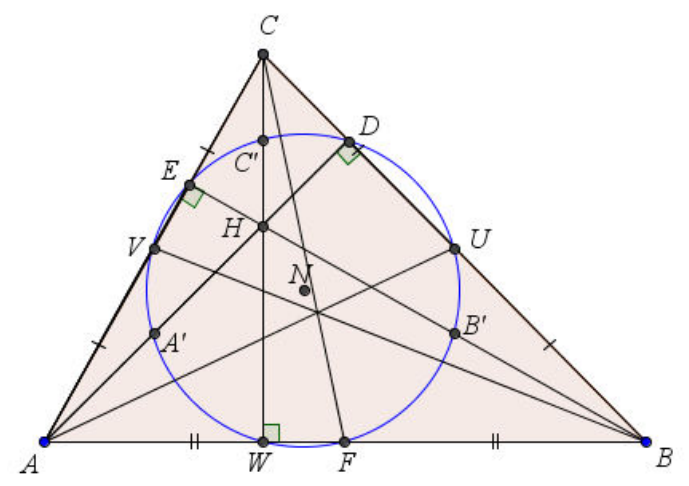

Gambar 1. Nine Point Circle 


$$
\begin{aligned}
& A V=\frac{1}{2} A C, B U=\frac{1}{2} B C, A W=\frac{1}{2} A B \\
& A A^{\prime}=\frac{1}{2} A H, B B^{\prime}=\frac{1}{2} B H, C C^{\prime}=\frac{1}{2} C H
\end{aligned}
$$

Berdasarkan teorema di atas, sembilan buah titik yang terletak pada sebuah lingkaran tersebut dapat diambil dari sebuah segitiga. Sembilan titik tersebut meliputi 3 titik yang merupakan titik tengah dari ketiga sisi segitiga, 3 titik yang merupakan kaki dari garis tinggi segitiga, dan 3 titik lagi merupakan titik tengah dari garis yang menghubungkan titik sudut segitiga dengan orthocentre-nya.

Dari teorema, diketahui bahwa dari sembilan titik tersebut, 6 (enam) buah titik merupakan titik tengah. Oleh sebab itu, pada pembuktian ini akan dimanfaatkan Teorema titik tengah. Dari penerapan teorema titik tengah didapatkan:

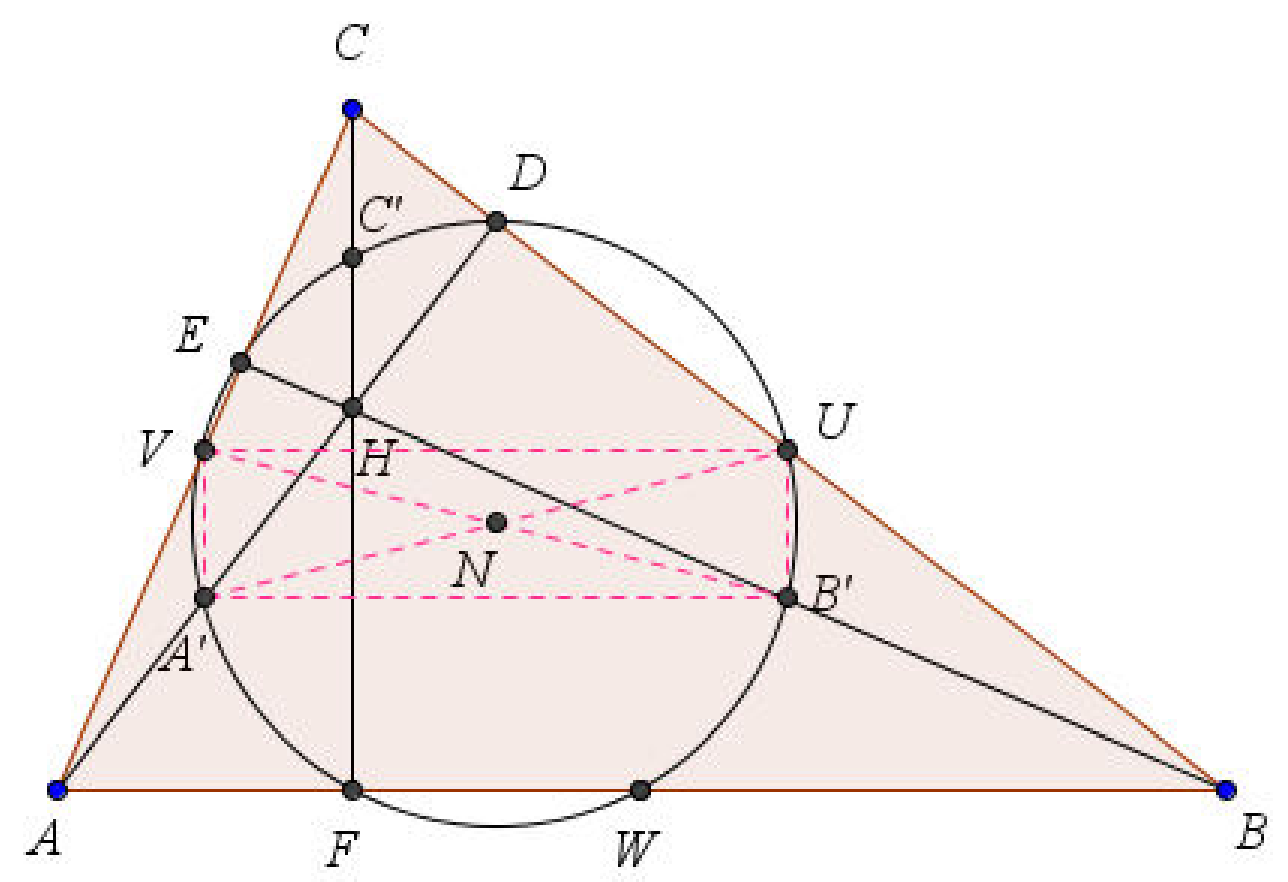

Gambar 2. Tahap 1 Pembuktian TeoremaNine Point Circle.

$\checkmark$ Pada $\triangle A B H, A^{\prime}$ titik tengah $\overline{A H}$ dan $B^{\prime}$ titik tengah $\overline{B H}$, sehingga didapatkan $\overline{A^{\prime} B^{\prime}} / / \overline{A B}$. 
$\checkmark$ Pada $\triangle A B C, V$ titik tengah $\overline{A C}$ dan $U$ titik tengah $\overline{B C}$, sehingga didapatkan $\overline{U V} / / \overline{A B}$.

$\checkmark$ Pada $\triangle A C H, A^{\prime}$ titik tengah $\overline{A H}$ dan $V$ titik tengah $\overline{A C}$, sehingga didapatkan $\overline{A^{\prime} V} / / \overline{C H}$.

$\checkmark$ Pada $\triangle B C H, B$ ' titik tengah $\overline{B H}$ dan $U$ titik tengah $\overline{B C}$, sehingga didapatkan $\overline{B^{\prime} U} / / C H$.

Karena $\overline{A^{\prime} B^{\prime}} / / \overline{A B}$ dan $\overline{U V} / / \overline{A B}$ maka $\overline{A^{\prime} B^{\prime}} / / \overline{U V} / / \overline{A B}$ dan karena $\overline{A^{\prime} V} / / \overline{C H}$ dan $\overline{B^{\prime} U} / / \overline{C H}$ maka $\overline{A^{\prime} V} / / \overline{B^{\prime} U} / / \overline{C H}$.

$\overline{C F}$ merupakan garis tinggi, sehingga $\overline{C F} \perp \overline{A B}$ yang berakibat $\overline{C H} \perp \overline{A B}, \overline{C H} \perp \overline{A^{\prime} B^{\prime}}$, atau $\overline{C H} \perp \overline{U V}$.

Ini berakibat, $m \angle A^{\prime} B^{\prime} U=m \angle B^{\prime} U V=m \angle U V A^{\prime}=m \angle V A^{\prime} B^{\prime}=90^{\circ}$. Dari alasan tersebut $A^{\prime} B^{\prime} U V$ merupakan persegi panjang.

Perpotongan diagonal $\overline{A^{\prime} U}$ dan $\overline{B^{\prime} V}$ yaitu di $N$ merupakan titik tengah dari $\overline{A^{\prime} U}$ dan juga merupakan titik tengah dari $\overline{B^{\prime} V}$ (karena $A^{\prime} B^{\prime} U V$ persegi panjang).Itu berarti titik $N$ merupakan pusat lingkaran yang melalui titik sudut dari persegi panjang $A^{\prime} B^{\prime} U V$. Jadi titik $A^{\prime}, B^{\prime}, U$ dan $V$ berada pada lingkaran yang berpusat di $N$.

Dari persegi panjang $\mathrm{A}^{\prime} \mathrm{B}^{\prime} \mathrm{UV}$ didapatkan $\angle A^{\prime} V U=90^{\circ}$. Dilain pihak karena $A D$ garis tinggi maka $m \angle A^{\prime} D U=90^{\circ}$. Sesuai dengan teorema sudut keliling lingkaran,diperoleh bahwa titik $D$ terletak pada lingkaran dengan pusat $N$ tersebut.

Dengan analogi yang sama, dapat ditunjukkan $B^{\prime} C^{\prime} V W$ dan $C^{\prime} A^{\prime} W U$ juga merupakan persegi panjang.

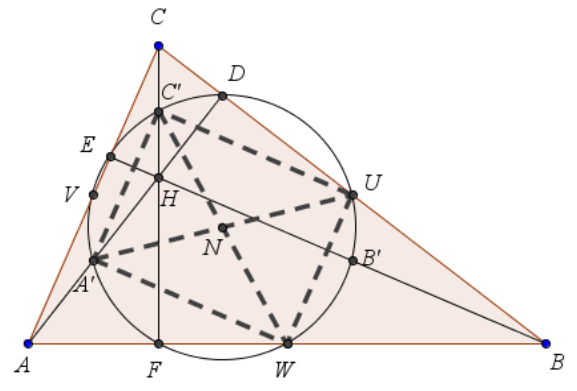

(a)

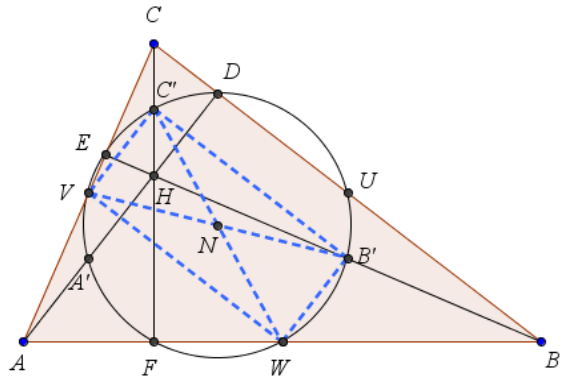

(b)

Gambar 3. Tahap 2 Pembuktian Teorema Nine Point Circle. 
Dengan cara yang sama dari Gambar 3 dapat diperoleh bahwa: (a) $A^{\prime}, W, U$, $C^{\prime}$ dan $F$ berada pada lingkaran yang berpusat di $N$; (b) $V^{\prime}, W, B^{\prime}, C^{\prime}$ dan $E$ berada pada lingkaran yang berpusat di $N$.

Jadi terbukti sembilan titik yaitu $A^{\prime}, B^{\prime}, C^{\prime}, D, E, F, U, V$, dan $W$ terletak pada lingkaran dengan pusat $N$.

\section{METODE}

Metode yang digunakan dalam seminar ini bersifat studi literatur, yaitu mengumpulkan, mempelajari dan memahami berbagai referensi yang berkaitan dengan segitiga dan lingkaran.Selanjutnya mencari hubungan antara nine point circle dan circumcircle segitiga. Hubungan yang dimaksud adalah hubungan Nine Point Circle dengan Circumcircle Suatu Segitiga ditinjau dari Jari-arinya serta ditinjau dari jarak titik pusat ke perpotongan ketiga garis tinggi segitiga (orthocentre).

\section{PEMBAHASAN}

Melalui tiga titik yang tidak segaris selalu dapat dibuat tepat satu lingkaran.Namun hal tersebut tidak berlaku jika diambil empat titik yang tidak segaris. Apalagi bila diambil sembilan titik yang tidak segaris, maka akan semakin sulit untuk mengkondisikan sembilan titik tersebut agar berada pada satu lingkaran. Sembilan titik tersebut dapat diperoleh dari sebarang segitiga, dan lingkaran yang melalui sembilan titik tersebut disebut nine point circle. Untuk mengkonstruksi nine point circle dari sebuah segitiga dengan baik dan cepat, harus melalui beberapa tahapan.Adapun tahapan-tahapan tersebut adalah sebagai berikut.

1. Gambar sebarang segitiga, misal $\triangle A B C$ seperti pada Gambar 4 berikut.

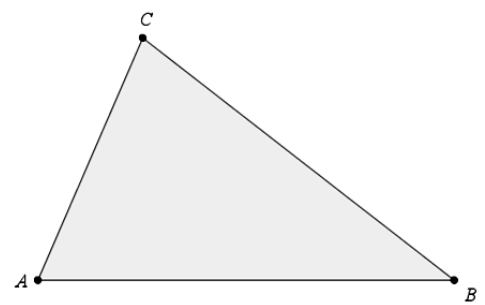

Gambar 4.Tahap 1 dalam Mengkonstruksi Nine Point Circle. 
2. Tentukan titik tengah dari masing-masing sisi segitiga tersebut, misal titik $U, V$ dan $W$ seperti pada Gambar 5 berikut.

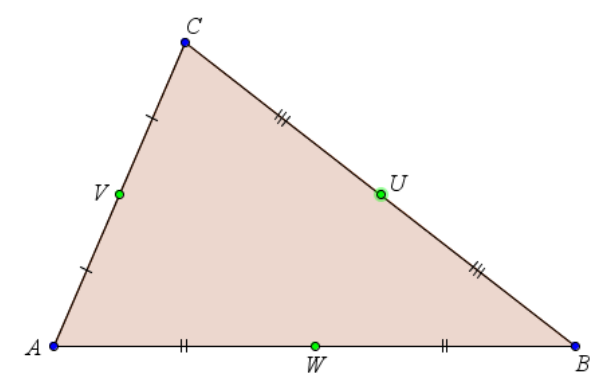

Gambar 5.Tahap 2 dalam Mengkonstruksi Nine Point Circle.

3. Gambar ketiga garis tinggi dari segitiga tersebut, dan beri nama titik potong dari masing-masing garis tinggi dengan sisi yang dipotongnya. Misalkan beri nama $D, E$, dan $F$. Garis tinggi ini akan berpotongan di satu titik yang disebut orthocentre, misal titik tersebut adalah $H$ seperti pada Gambar 6 berikut.

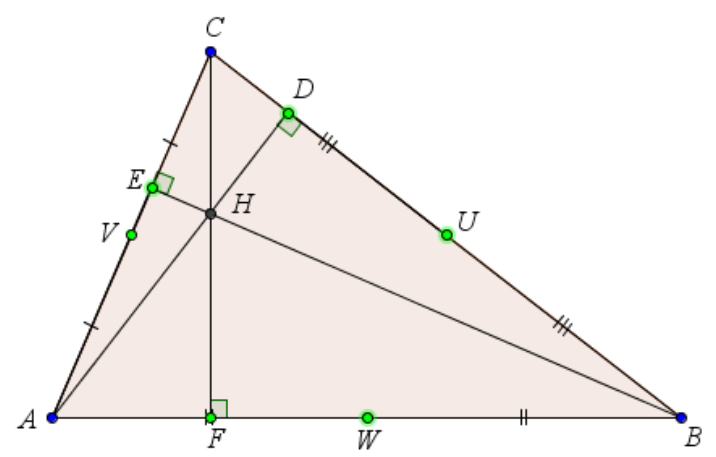

Gambar 6.Tahap 3 dalam Mengkonstruksi Nine Point Circle.

4. Tentukan titik tengah dari ruas garis $\overline{A H}, \overline{B H}$, dan $\overline{C H}$, misal $A^{\prime}, B^{\prime}$, dan $C^{\prime}$ seperti pada Gambar 7 berikut.

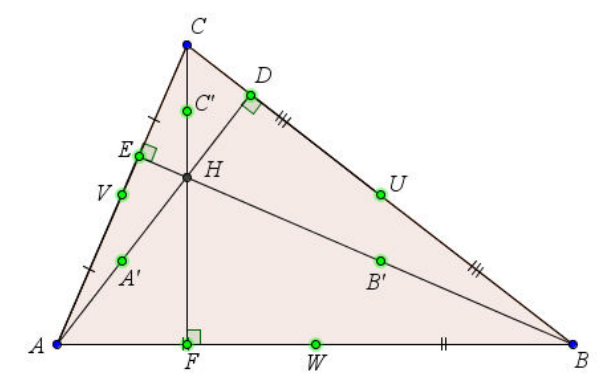

Gambar 7.Tahap 4 dalam Mengkonstruksi Nine Point Circle.

Sembilan titik tersebut yaitu titik $U, V, W, D, E, F, A^{\prime}, B^{\prime}$ dan $C^{\prime}$ terletak pada sebuah lingkaran. 
5. Untuk menentukan pusat dari nine point circle, hanya dengan menentukan titik tengah dari $\overline{A^{\prime} U}$, misal $N$ seperti pada Gambar 8 berikut.

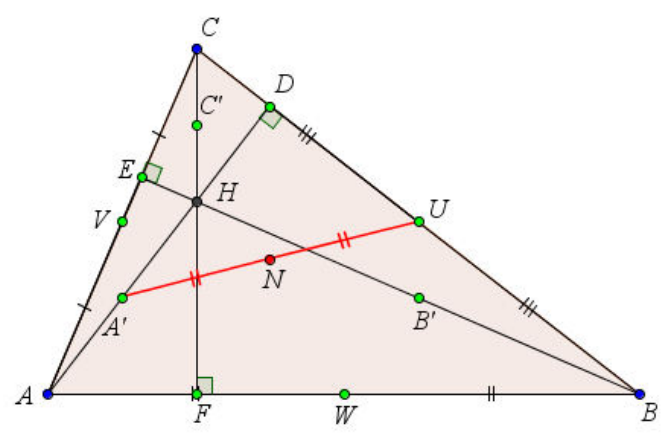

Gambar 8.Tahap 5 dalam Mengkonstruksi Nine Point Circle.

Catatan : pusat nine point circle juga dapat ditentukan dengan menentukan pusat lingkaran luar $\Delta U V W$ yaitu pada perpotongan garis sumbu dari masing-masing sisi $\Delta U V W$ seperti pada Gambar 9 berikut.

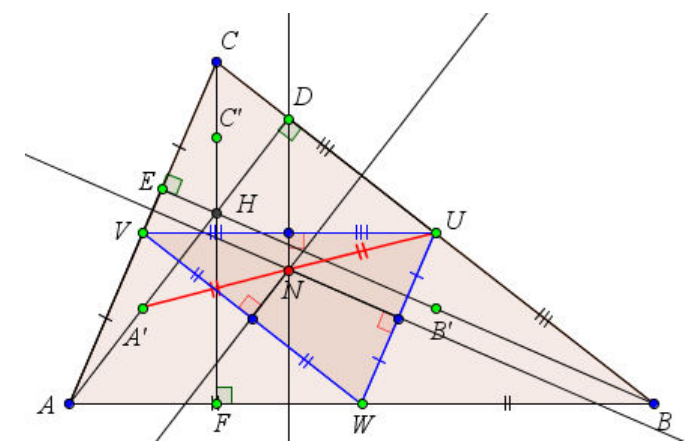

Gambar 9. Cara Lain Menentukan Pusat Nine Point Circle.

6. Gambarlah lingkaran dengan titik pusat $N$ dan melalui sembilan titik yaitu titik $U, V, W, D, E, F, A^{\prime}, B^{\prime}$ dan $C^{\prime}$.Lingkaran inilah yang disebut nine pont circle, sehingga nine point circle dari $\triangle A B C$ adalah lingkaran dengan pusat $N$ dan jari-jari $N A$ seperti pada Gambar 10 berikut.

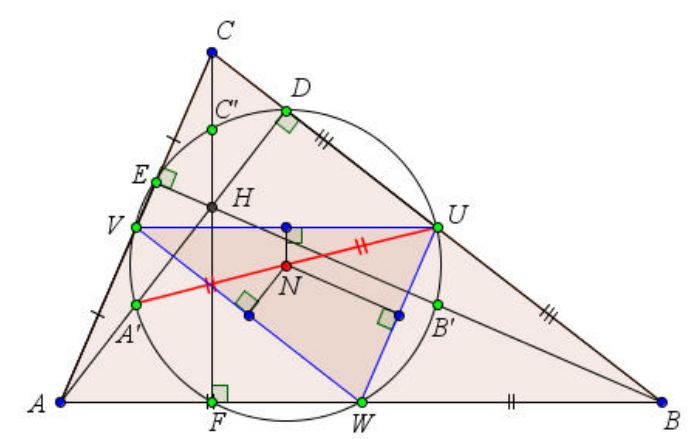

Gambar 10.Tahap 6 dalam Mengkonstruksi Nine Point Circle. 
Menurut Teorema nine point circle dan Teorema lingkaran luar (circumcircle) segitiga, melalui sebarang segitiga selalu dapat dibuat lingkaran luar dan nine point circle. Pada pembahasan berikut penulis akan mengkaji mengenai hubungan antara nine point circle dengan circumcircle suatu segitiga. Namun hubungan yang dimaksud disini terbatas pada hubungan yang ditinjau dari jari-jarinya dan jarak titik pusat dari masing-masing lingkaran ke orthocentre segitiga tersebut.

Pada pembahasan berikut akan dikaji mengenai hubungan nine point circle dengan circumcircle suatu segitiga yang memuat nine point circle tersebut, ditinjau dari jari-jarinya.

Perhatikan Gambar 11 berikut!

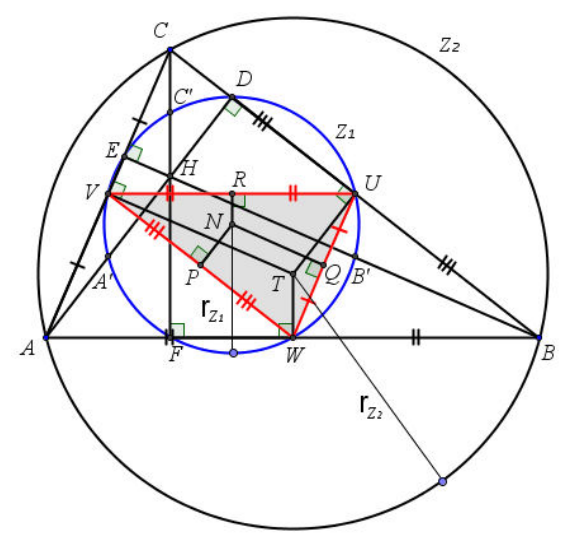

Gambar 11.Hubungan Nine Point Circle dengan Circumcircle Suatu

Segitiga.Ditinjau dari Jari-arinya.

Berdasarkan Gambar 11 di atas, $Z_{1}$ adalah nine point circle dari $\triangle A B C$ dan $Z_{2}$ adalah lingkaran luar (circumcircle)dari $\triangle A B C$. Akan diselidiki mengenai hubungan antara jari-jari $Z_{1}$ dan $Z_{2}$.

Selain sebagai nine point circle dari $\triangle A B C, Z_{1}$ juga merupakan curcumcircle dari $\Delta U V W$ dimana $U, V$ dan $W$ merupakan titik tengah dari masing-masing sisi $\triangle A B C$, sehingga sesuai teorema titik tengah diperoleh $U V=\frac{1}{2} A B, V W=\frac{1}{2} B C$, dan $W U=\frac{1}{2} C A$, yang berakibat $L_{\triangle U V W}=\frac{1}{4} L_{\triangle A B C}$. 
Misalkan $r_{Z_{1}}$ sebagai jari-jari dari $Z_{1}$ dan $r_{Z_{2}}$ sebagai jari-jari $Z_{2}$. Berdasarkan teorema jari-jari lingkaran luar segitiga yang ditentukan dengan rumus: $r=\frac{a b c}{4 L \Delta}$ dimana $a, b, c$ merupakan panjang sisi segitiga diperoleh bahwa.

$$
\begin{aligned}
r_{Z_{2}}: r_{Z_{1}} & =\frac{a b c}{4 L_{\triangle A B C}}: \frac{u v w}{4 L_{\triangle U V W}} \\
& =\frac{a b c}{4 L_{\triangle A B C}}: \frac{\frac{1}{8} a b c}{4\left(\frac{1}{4} L_{\triangle A B C}\right)} \\
& =\frac{a b c}{4 L_{\triangle A B C}}: \frac{a b c}{8 L_{\triangle A B C}} \\
& =\frac{1}{4}: \frac{1}{8} \\
& =2: 1 \\
r_{Z_{2}} & =2 r_{Z_{1}}
\end{aligned}
$$

Berdasarkan uraian di atas dapat disimpulkan bahwa jari-jari lingkaran luar (circumcircle) dari $\triangle A B C$ sama dengan dua kali jari-jari nine point circle dari $\triangle A B C$.

Jari-jari nine point circle sama dengan setengah jari-jari lingkaran luar (circumcircle) segitiga yang memuat nine point circle tersebut.

Pada pembahasan berikut akan dikaji lebih lanjut mengenai hubungan nine point circle dengan circumcircle ditinjau dari jarak titik pusatnya ke orthocentre suatu segitiga yang memuat nine point circle dan circumcircle tersebut. Perhatikan Gambar 12 berikut! 


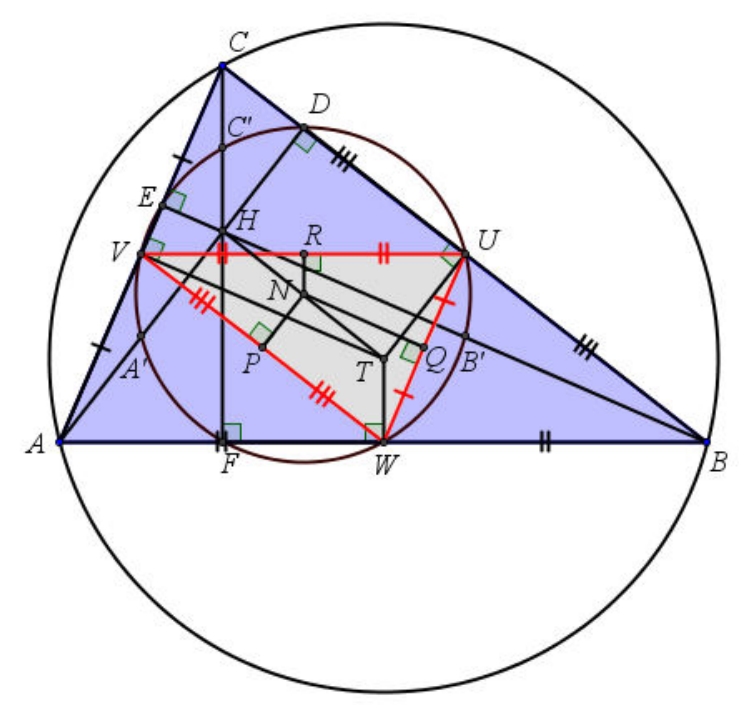

Gambar 12.HubunganNine Point Circle dengan Circumcircle Ditinjau dari Jarak Titik Pusatnya ke Orthocentre Segitiga.

Pada Gambar 12, titik $T$ adalah titik pusat circumcircle dari $\triangle A B C$, titik $H$ adalah orthocentre dari $\triangle A B C$ dan titik $N$ adalah titik pusat nine point circle dari $\triangle A B C$. Akan dikaji mengenai hubungan antara jarak titik pusat nine point circle ke orthocentre $\triangle A B C$ dengan jarak titik pusat circumcircle ke orthocentre $\triangle A B C$.Pengkajian dilakukan melalui beberapa tahapan sebagai berikut.

1. Pada Gambar 12, perhatikan $\triangle A B C, \triangle U V W, \overline{C F}, \overline{W T}, \overline{R N}$ dan $\overline{V T}$.

Misalkan perpanjangan $\overline{W T}$ memotong $\overline{U V}$ di $X, \overline{C F}$ memotong $\overline{U V}$ di $X^{\prime}$ dan $\overline{R N}$ memotong $\overline{V T}$ di $R$ ', seperti terlihat pada Gambar 13 berikut.

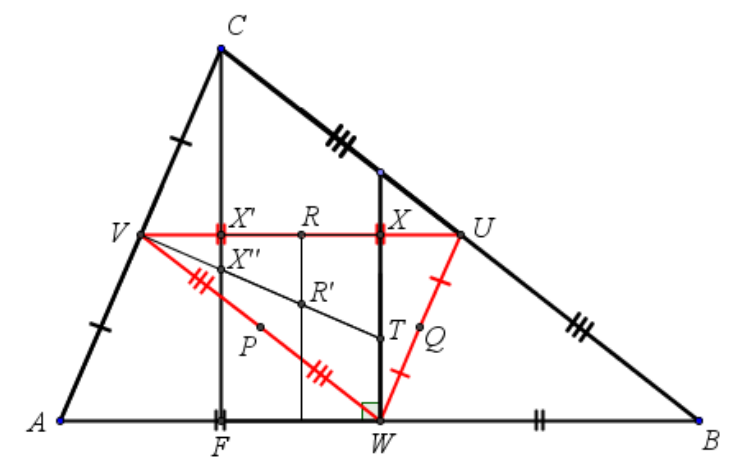

Gambar 13.Tahap 1 dalam Mencari HubunganNine Point Circle dengan Circumcircle Ditinjau dari Jarak Titik Pusatnya ke Orthocentre Segitiga. 
Berdasarkan teorema titik tengah, diperoleh $\overline{C A} / / \overline{U W}$ dan $\overline{C B} / / \overline{V W}$. Ini berarti segiempat $U C V W$ merupakan suatu jajar genjang, sehingga menurut teoremadiperoleh $\overline{C V} \cong \overline{U W}$. Selain itu,

$m \angle C V X^{\prime}=m \angle X U W$ (pasangan sudut dalam berseberangan) dan

$m \angle V C X^{\prime}=m \angle U W X$ (pasangan sudut dalam berseberangan).

Oleh sebab itu, berdasarkan Teorema sudut-sisi-sudut diperoleh $\triangle \mathrm{VCX}^{\prime} \cong \triangle U W X$ yang berakibat $\overline{V X^{\prime}} \cong \overline{U X}$.

Titik $R$ merupakan titik tengah dari $\overline{U V}$ dan $\overline{V X^{\prime}} \cong \overline{U X}$, oleh karena itu dapat disimpulkan bahwa titik $R$ juga merupakan titik tengah dari $\overline{X X^{\prime}}$ yang berakibat $\overline{X^{\prime} R} \cong \overline{R X}$.

Dapat diselidiki bahwa $R X^{\prime} X^{\prime \prime} R^{\prime} \sim X X^{\prime} X^{\prime \prime} T$, sehingga berlaku

$$
\begin{array}{ll}
\frac{X^{\prime} R}{X^{\prime} X} & =\frac{X^{\prime \prime} R^{\prime}}{X^{\prime \prime} T} \\
\frac{X^{\prime} R}{X^{\prime} R+R X} & =\frac{X^{\prime \prime} R^{\prime}}{X^{\prime \prime} T} \\
\frac{X^{\prime} R}{X^{\prime} R+X^{\prime} R} & =\frac{X^{\prime \prime} R^{\prime}}{X^{\prime \prime} T} \\
\frac{X^{\prime} R}{2 X^{\prime} R} & =\frac{X^{\prime \prime} R^{\prime}}{X^{\prime \prime} T} \\
\frac{1}{2} & =\frac{X^{\prime \prime} R^{\prime}}{X^{\prime \prime} T} \\
X^{\prime \prime} T & =2 X^{\prime \prime} R^{\prime} \\
R^{\prime} T=X^{\prime \prime} T-X^{\prime \prime} R^{\prime}=2 X^{\prime \prime} R^{\prime}-X^{\prime \prime} R^{\prime}=X^{\prime \prime} R^{\prime}
\end{array}
$$

Jadi $R^{\prime} T=X^{\prime \prime} R^{\prime}$

2. Pada Gambar 12, perhatikan $\triangle A B C, \triangle U V W, \overline{B E}, \overline{R N}, \overline{W T}, \overline{Q N}$ dan $\overline{V T}$.

Misalkan perpanjangan $\overline{W T}$ memotong $\overline{Q N}$ di $Q^{\prime}$ dan $\overline{B E}$ di $Y^{\prime \prime}, \overline{W U}$ memotong $\overline{B E}$ di $Y^{\prime}$ dan perpanjangan $\overline{V T}$ di $Y$ seperti terlihat pada Gambar 14 berikut. 


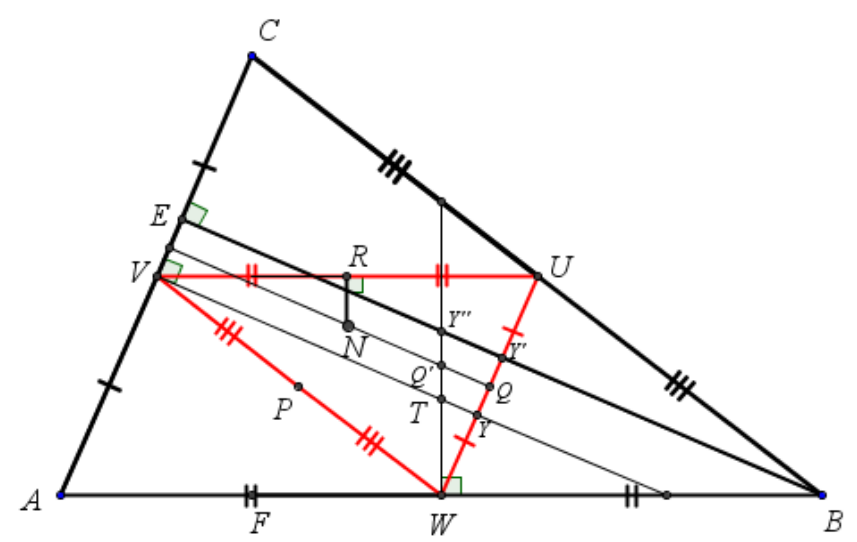

Gambar 14.Tahap 2 dalam Mencari HubunganNine Point Circle dengan

Circumcircle Ditinjau dari Jarak Titik Pusatnyake Orthocentre Segitiga.

Dengan cara yang sama seperti pada tahap 1 (pertama) diperoleh $\triangle \mathrm{VWY} \cong \triangle B U Y^{\prime} \quad$ (berdasarkan teorema sudut-sisi-sudut) yang berakibat $\overline{W Y} \cong \overline{U Y^{\prime}}$.

Titik $Q$ merupakan titik tengah dari $\overline{W U}$ dan $\overline{W Y} \cong \overline{U Y^{\prime}}$. Oleh karena itu dapat disimpulkan bahwa titik $Q$ juga merupakan titik tengah dari $\overline{Y Y^{\prime}}$ yang berakibat $\overline{Y^{\prime} Q} \cong \overline{Q Y}$. Selain itu, dapat diselidiki bahwa $Q Q^{\prime} T Y \sim Y^{\prime} Y^{\prime \prime} T Y$, sehingga dengan cara yang sama seperti pada tahap 1 (pertama) diperoleh, $T Q^{\prime}=Q^{\prime} Y^{\prime \prime}$.

3. Perhatikan Gambar 15 berikut!

Gambar 15 ini merupakan gabungan dari Gambar 13 dan Gambar 14.

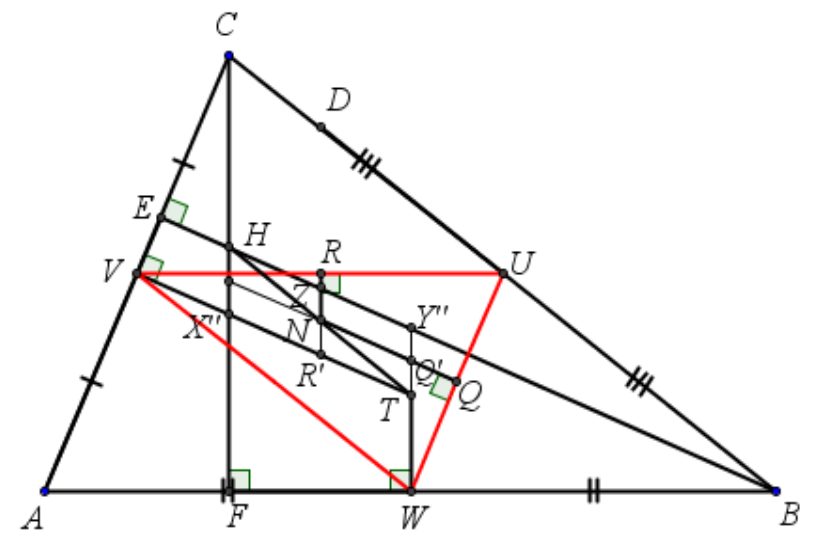

Gambar 15.Tahap 3 dalam Mencari Hubungan Nine Point Circle dengan Circumcircle Ditinjau dari Jarak Titik Pusatnya ke Orthocentre Segitiga.

Pada tahap 1 (pertama), telah diperoleh $R^{\prime} T=X^{\prime \prime} R^{\prime}$. 
$C F / / R N$ dan $V T / / B E$. Oleh sebab itu, bangun $H X^{\prime \prime} R^{\prime} Z$ merupakan jajar genjang. Dengan demikian berlaku $X^{\prime \prime} R^{\prime}=H Z$

Karena $R^{\prime} T=X^{\prime \prime} R^{\prime}$ dan $X^{\prime \prime} R^{\prime}=H Z$, dapat disimpulkan $R^{\prime} T=H Z$.

$N R^{\prime} / / Q^{\prime} T$ dan $R^{\prime} T / / N Q^{\prime}$. Oleh karena itu, segiempat $N R^{\prime} T Q^{\prime}$ merupakan jajar genjang.Dengan demikian berlaku $R^{\prime} T=N Q^{\prime}$.

Karena $R^{\prime} T=H Z$ dan $R^{\prime} T=N Q^{\prime}$,

dapat disimpulkan $H Z=N Q^{\prime}$

Pada tahap 2 (kedua), telah diperoleh $T Q^{\prime}=Q^{\prime} Y^{\prime \prime}$.

$Z N / / Y^{\prime \prime} Q^{\prime}$ dan $N Q^{\prime} / / Z Y^{\prime \prime}$, Oleh karena itu segiempat $Z N Q^{\prime} Y^{\prime \prime}$ merupakan jajar jenjang. Dengan demikian berlaku $Z N=Y^{\prime \prime} Q^{\prime}$

Karena $T Q^{\prime}=Q^{\prime} Y^{\prime \prime}$ dan $Z N=Y^{\prime \prime} Q^{\prime}$,

dapat disimpulkan $Z N=T Q^{\prime}$

$m \angle H Z N=m \angle Z Y^{\prime \prime} Q^{\prime}($ pasangan sedut sehadap)

$m \angle Z Y^{\prime \prime} Q^{\prime}=m \angle N Q^{\prime} T$ (pasangan sudut sehadap)

Dapat disimpulkan $m \angle H Z N=m \angle N Q^{\prime} T$.

Berdasarkan Postulat sisi-sudut-sisi, dari (i), (ii) dan (iii), dapat disimpulkan bahwa $\triangle H Z N \cong \triangle N Q^{\prime} T$ yang berakibat $m \angle Z H N=m \angle Q^{\prime} N T$. Karena $E B / / N Q^{\prime}$ dan $m \angle Z H N=m \angle Q^{\prime} N T$, maka $\angle Z H N$ dan $\angle Q^{\prime} N T$ merupakan pasangan sudut sehadap. Dengan demikian haruslah $H, N$, dan $T$ berada dalam satu garis.

Selain itu, karena $\triangle H Z N \cong \triangle N Q^{\prime} T$, diperoleh $H N=N T$. Ini berarti $N$ merupakan titik tengah dari $\overline{H N}$.

Karena $H, N$, dan $T$ berada dalam satu garis dan $H N=N T$, sehingga diperoleh $H T=H N+N T=H N+H N=2 H N$.

Berdasarkan paparan di atas, diperoleh hubungan bahwa jarak $N$ ke $H$ sama dengan setengah jarak $T$ ke $H$. 
Jarak titik pusat nine point circle ke orthocentresama dengan setengah jarak titik pusat circumcircle ke orthocentre suatu segitiga.

\section{SIMPULAN}

Untuk mengkonstruksi nine point circle dari suatu segitiga dapat dilakukan melalui tahapan-tahapan yang meliputi: (a) menggambar sebarang segitiga; (b) menentukan titik tengah dari masing-masing sisi segitiga tersebut; (c) menentukan titik potong dari garis tinggi segitiga dengan sisi-sisi segitiga; (d) menentukan titik tengah dari masing-masing titik sudut dengan orthocentre, sehingga didapatkan sembilan buah titik yang terletak pada sebuah lingkaran yang disebut nine point circle; (e) menentukan titik pusat nine point circle dengan mencari titik tengah antara titik tengah dari salah titik sudut dan orthocentre dengan titik tengah dari salah satu sisi segitiga dihadapan titik sudut tersebut; (f) menggambar nine point circle.

Jari-jari nine point circle sama dengan setengah jari-jari lingkaran luar (circumcircle) suatu segitiga yang memuat nine point circle tersebut. Jarak titik pusat nine point circle ke orthocentre samadengan setengah jarak titik pusat circumcircleke orthocentre.

\section{DAFTAR RUJUKAN}

Ariawan, Wisna. 2014. Geometri Bidang.Yogyakarta:Graha Ilmu.

Oka.I Wayan Sadra. 2011. Nine Point Circle. Singaraja : Jurusan Pendidikan Matematika Undiksha ( tidak diterbitkan).

Hofstadter, Douglas R. 1992. Discovery and Dissection of a Geometric Gem.Indiana: Center for Research on Concepts \&Cognition Indiana University.

Sutherland, Scott. 2004. The Nine-Point Circle. [http://www.math.sunysb.edu/ $\sim$ scott/mat360.spr04/cindy/ninepoint.html, diakses pada tanggal 16 April 2015] 